\title{
Design of Poverty Reduction in Developing Countries Based on Entrepreneurship \\ Endang Naryono ${ }^{1^{*}}$ \\ Management Studies Program, PASIM College of Economics 'West Java, Indonesia \\ *Corresponding author email: endang@stiepasim.ac.id
}

\begin{abstract}
Poverty is a very complex problem to solve and find a solution, this is because poverty is highly correlated with various cross-sectors with one another that is interconnected so that breaking the poverty rate requires a strategy that is concrete, valid and of course sustainable. The purpose of this paper is to make a policy design in an effort to alleviate poverty in developing countries or poor countries that have low per capita income. The main problem in developing countries is that they do not have sufficient budgets to develop their countries so that in general the budget deficit is covered through foreign debt, then it is still dependent on investment from foreign investors in driving the economy, especially in the manufacturing, industry and infrastructure sectors because the state has not been able to afford it. to build it themselves due to the lack of budget, the low quality of human resources, this is due to the low level of education so that they do not have the competitiveness in competing in getting jobs, so that people who do not have competitiveness are finally excluded and fall into poverty. Policies in developing countries are generally still at the macroeconomic level, not at the micro-economic level in poverty alleviation so that the poverty rate, although there is a decline, is still very small compared to the ratio of poverty growth to population. One solution to overcome this poverty problem is to build an entrepreneurial spirit because entrepreneurship will have high economic value and have a very large multiplayer for economic growth.
\end{abstract}

Keywords: Poverty Alleviation Design, Developing Countries, Poverty, Indonesia

\section{Introduction}

The world is changing faster, this is greatly influenced by the development of increasingly massive scientific and technological advances and the distribution of information channels that do not recognize national boundaries but globally people can get them. The times have brought changes to all countries, they are competing to spur their economy as high as possible in the hope of prospering their people, but not all can enjoy it like developing countries and poor countries, the unemployment rate and poverty are still high which is a burden and a separate problem for the government. Budget constraints are an obstacle in the development of developing countries, the last resort is to invite investors to invest in their countries so that they can create jobs and increase people's purchasing power so that they can get out of the valley of poverty. In fact, foreign investment that enters, not all can enjoy it, this is due to the low quality of human resources owned so that when there is industrial development that creates high employment opportunities, there are groups of people who are marginalized because they cannot compete in the face of competition for jobs where the demand for employment is limited while the supply is high so that the number of the labor force is still high which cannot be absorbed which in turn creates unemployment.

Government policies in developing countries are still at the macroeconomic level not at the microeconomic level in alleviating poverty in developing countries such as spurring economic growth by inviting foreign investors to invest in the country in the hope of creating jobs and increasing power. buy people so that it will reduce poverty and unemployment. So that in this macroeconomic policy, there are still many people who have not been able to enjoy it, this is because they cannot compete in competition due to the low quality of human resources.

Micro-economic policies should be prioritized and focused on the grassroots so that they go straight to the core of the main problems in poverty such as providing educational scholarships, providing hardskill and soft-skill trainings and providing convenience for small businesses so that they can develop and progress so that they can become entrepreneurs. middle class and able to compete with advanced companies. Policies that require partnerships between large companies and small companies in the process of production, distribution to marketing so that the law of the jungle does not apply where the strong will live and the weak will perish. So that small businesses should not be made competitors by large companies but become partners of cooperation, of course, which are mutually beneficial, but in reality it is still difficult to materialize because usually in developing countries, especially those with open economic systems, where the economy is owned by the owners of capital, so that the most efficient applicable economic laws can 
survive so that massive industrialization or foreign investment sometimes becomes cannibalism that will kill existing small businesses.

Entrepreneurship is a real solution in overcoming poverty and unemployment with community entrepreneurship being demanded, creative, innovative and able to capture economic opportunities that can be utilized to improve their standard of living. Entrepreneurship makes people independent from other people, progressing or not depending on themselves so that entrepreneurship will form the souls of entrepreneurs who are always in a race against time in developing their business. More and more people who are entrepreneurship in the micro-economic world will indirectly move the real sector in the production process, distribution of goods and services, if this sector is running, then economists can move and grow, of course, it will be very beneficial for the country in alleviating poverty.

\section{Become Entrepreneurs}

In 2020 to mid-2021, the global economy experienced a sharp contraction and led to an economic recession. One of the contributing factors is the COVID-19 pandemic which has brought about an extraordinary humanitarian disaster, its impact not only on health but has spread to all sectors, one of which is the economy. As a result of this pandemic, people's purchasing power is low which causes the production sector to stop, of course this will result in low public consumption which will ultimately lead to increased poverty. The cessation of the production sector resulted in an increase in unemployment due to massive layoffs in the real sector. Government policies in dealing with COVID-19 are like two legs between health or the economy because both are equally important. One of the most effective policies that focus on small and medium-sized economies as well as providing social security, this policy is expected to stimulate the production sector and increase people's purchasing power.

In the midst of the difficulty of employment, the labor force is not absorbed in the field of work so that unemployment is increasing. Even if there are job seekers, they have to compete with people who have much experience in finding work. Who can these people rely on to overcome all that? The answer is entrepreneurship. In Indonesia's development system at that time, although its economic contribution was still low and limited, there were tens of millions who were involved. Most of today's small and medium enterprises are the backbone of Indonesia's national economy. These businesses do not yet have a large number of employees, are managed only by a few entrepreneurs, they are independent, resilient, flexible and mobile, efficient because they are carried out with all family members, not very dependent on debt and based on local resources owned.

Most of the small and medium enterprises at that time had not been managed in a modern way, but they were free from crises because of the characteristics described above. Most of them had not implemented modern management such as using separate management of personal and company assets. Have not used a Brand, have not used well-managed financial records (accounting), have not had a written division of labor, have not had or used SOP (Standard Operational Procedure) have not used knowledge management and so on.

However, the economic crisis has actually awakened the majority of small and medium-sized enterprises when they realize the importance of all of this, they are even able to take a larger portion, recruit more workers and so on. Economy Most small and medium enterprises currently become a foundation and a very important choice for job seekers to get a better and prosperous life, be more independent and help many people to overcome the problem of unemployment. Not by being an employee but by being an entrepreneur.

\section{Entrepreneurship Is Not Just Survival}

Micro and Small Medium Enterprises have become the main pillar and spearhead of the national economy. It's just that not all entrepreneurs are entrepreneurs, an entrepreneur is someone who tries with courage and persistence so that his business grows and improves. So growth is the key to being an entrepreneur. Thus there are millions of people who choose not to work for others. But they cannot be said to be an entrepreneur if they just open a shop, try to make modest efforts, just to survive, then they are just traders. Their characteristics are business and stagnant, there will be no changes from time to time and are carried out without any progress plans at all.

An entrepreneur is someone who is moving forward and moving forward. His business grew over time from one shop to two shops, ten shops, a hundred shops from a small business to a large one, no matter whether an academic, an artist, a social worker or an industrialist. Who did it. We can be said to be an entrepreneur as long as we grow on a growth foundation, therefore an entrepreneur concept is widely 
known, ranging from business entrepreneurs, creative entrepreneurs, technopreneurs, to social entrepreneurs.

\section{Friends with Uncertainty}

One of the cores of an entrepreneur or an entrepreneur is a friendship that is thick with uncertainty. Unlike those who choose a profession as a worker, manager, or professional executive, an entrepreneur deals with uncertainty from time to time. To avoid an uncertainty, many scholars and even masters in the past chose to work as employees and later become managers. Small salary is not a problem as long as it is certain. Every month with the same date earns a fixed income. Every year there is a promotion, you can change jobs, get a better position, get a bigger salary and benefits. If you are married, your wife and children will get other benefits. Everything is definitely obtained from the workplace.

So what about an entrepreneur? The situation turned 180 degrees. There is no fixed income (unless the business is stable) all the facilities enjoyed must be paid for from the money that is sought by yourself. Even in the early stages of building a business, there are many difficulties. Do not have adequate expertise, let alone trust. All of that must be built step by step starting with various challenges. For an entrepreneur, a difficulty is not the end of everything, with a motto a winner will never give up. Only those who give up and quit will never be winners. For an entrepreneur difficulty is a challenge. Because in their heads they always have beautiful final goals in mind. Their thoughts are not on that day alone. but someday.

Because not many people dare to be friends with uncertainty, so many people are lost in the valley of uncertainty. Whereas the new days in Indonesia after the reform of the new order, and also throughout the world (post-cold war) are uncertain. The world has changed to be very complex, nature has changed completely, as well as human relations, technology and competition. Everything changes so fast and is able to overcome it only those who are friends with uncertainty itself, they are friendly, know very well the characters of uncertainty and are able to take great benefit from it, that's an entrepreneur

\section{Real Effort}

The real business is a vast ocean that an entrepreneur is engaged in, he does not know shortcuts, especially with quick ways to get rich. After all, being rich is not an entrepreneur's goal. Rich is the result of honest business behavior. The result of hard work and trust. All of that is obtained from efforts that require time and sincerity. The purpose of an entrepreneur's life is to live independently and be happy.

He can manage his time freely, make decisions, determine the direction of the future, and see so many people being helped by having an income. But on the other hand he works and thinks all the time, we take risks and make up for the limits of our difficulties in serving people because without that desire we will not get customers.

This real business is different from speculative businesses filled with slogans, taglines, how to get rich quick. As we are currently getting promos through social media, Whatsapp and SMS, there are many that offer a quick way to get rich. Just open an account and transfer money and just wait for the money to come in. No need to work hard but earn income in no time. That's a business that is less intelligent, tends to be stupid, which is only based on win-lose and speculative principles.

Speculative efforts are shown to pursue a wealth in a short time, without hard work by avoiding risk. Wealth for this group is the main goal so for them welfare is rich. In business parlance, this is referred to as illusionary wellth because such wealth usually does not bring prosperity and does not lead to happiness.

In many cases, speculative efforts are actually very dangerous for their own owners, they become greedy, never satisfied, many do unethical acts, harm many people, become fugitives from the police and are blasphemed by many people. They never get respect and don't get happiness. Now these speculative efforts are also widely offered through the media and ensnare many prospective scholars because they promise instant ways. Among the speculative efforts, money games are very wide ranging from just savings, using quota vouchers, clothing, gold bullion to ducks and farming in the mountains.

Speculative ventures are not the area of an entrepreneur because they do not require a hard work, reputation or pursuit of happiness. For those who are important themselves and obtained in a short time.Mendeteksi Usaha Spekulatif The millennial generation is now surrounded by various speculative businesses, even in developed countries such as the United States, many of which went bankrupt and experienced an economic crisis in 2007 to 2010 due to speculative businesses. Meanwhile, in Indonesia, new businesses are starting to arrive, which trade and offer which is actually a speculative business that is very detrimental to many people. We find many examples in everyday life that offer various conveniences with very promising benefits and small risks, from flyers on the road, advertisements, social media to SMS or Telephone. 


\section{Entrepreneurial Mindset}

1. The basic characteristics of an entrepreneur are the basis of an entrepreneur. According to McGraith \& Mac Millan (2000), there are seven basic characters that every aspiring entrepreneur needs to have. The seven characters can be explained as follows.

2. Action-oriented. Not the type to procrastinate, wait and see or let things or opportunities pass you by. we don't wait until things are clear first. Or the budget is there first. We also do not wait for uncertainty to go first, then try. They are people who want to act immediately, even if the situation is uncertain (Uncertain). Their principle is see and do. For them risk is not to be avoided but to be faced and conquered with action and shrewdness,

3. Simple Thinking. Even though the world has changed to become very complex, they have always simplified it. And even though they have high knowledge, they are not technical people who are complicated and want complex work. They see problems clearly and solve problems one by one step by step.

4. They look for new opportunities. Is it a real business opportunity or an opportunity of the same business. For new businesses, they are always willing to learn new things, form a network from below and add to their business landscape or scope, while in the same business, they are always diligent in looking for new alternatives such as models, designs, platforms, raw materials, energy, packaging. and production cost structure. They profit not only from new business or products but also from new ways.

5. Pursue Opportunities With high discipline.

An entrepreneur is not only alert, has a sharp eye in capturing an opportunity, but they move towards it. Opportunities are not only sought but created, opened and clarified. Because entrepreneurs invest and take risks, an entrepreneur must have high discipline. Successful entrepreneurs are not lazy or procrastinators. They want the job done and what they think can be carried out immediately. They fight with time and opportunity is always related to time. What is an opportunity at one time may not always be an opportunity at another time. Once again the opportunity is lost, will not necessarily come back again. Every brilliant idea and innovation usually has to be built from the ground up and built across the value chain.

6. Take only the best opportunities. An entrepreneur will become very alert and have a keen sense of smell in time. Very different from beginners who have not been trained and are still confused, then a trained entrepreneur will quickly read opportunities but a true entrepreneur will only take the best opportunities. An interesting measure of that is the economic scale contained in it. A brighter future, the ability to show the values of achievement, and the resulting changes. All of this is usually associated with feelings of liking for the object of business or the belief that he is able to realize it.

In the end, the success achieved by each person is determined by the success of that person in choosing. Success is a function of the success of choosing, whether choosing a school, career, line of business, friends, spouse, employees / executives, business partners and so on. The best choice will determine the results that can be achieved.

7. Focus on execution An entrepreneur is not someone who only struggles with contemplating thoughts and testing hypotheses. Rather someone who focuses on execution. They do not want to stop at the exploration of the mind or just spinning in the mind full of human doubts with an entrepreneurial mindset to execute, which is to take action and realize what they are thinking rather than analyzing new ideas to death. (McGraith and Mac Millan, 2000:3). They are also adaptive to situations, which are easy to adjust to new facts or difficulties in the field.

8. Focus everyone's energy on the business they are in.

An entrepreneur does not work alone. He uses the hands and minds of many, both inside and outside the company. They build a network instead of doing everything on their own. Like a music conductor, he gathers musicians who are experts in playing different instruments to produce musical notes that are liked by the audience. So he must have the ability to gather people to build networks, lead, unite movements, motivate and communicate.

\section{Entrepreneurial Mindset}

Finally, everyone who takes on a role or career as an entrepreneur needs to know what options are available by becoming an employee. Entrepreneur, entrepreneur or social entrepreneur. The explanation can be described as follows.

a. Employees: you work for other people and if successful you can achieve a career as a professional executive with a role as a decision maker 
b. Intrapreneur: your status is you are an employee, you work for someone else you have a boss but what you are looking for is independence and access to resources and you have entrepreneurship

c. Entrepreneur: you don't work for other people, but rather a business that you develop yourself. You are the owner of the freedom to manage your business direction, make strategic decisions you can run it yourself or use professionals. You bear the risk but also enjoy the benefits of the business after paying employee salaries and other obligations.

d. Social entrepreneur: actors in social activities who are entrepreneurial. Some of you may think that you prefer to work in the social field or start a community organization. Such as education, health, environment, community empowerment, legal protection, human rights, arts or other fields. By having an entrepreneurial character, you can promote social activities so that your social activities can become more independent and sustainable, and not just donations.

\section{Conclutsion}

1. The main capital of entrepreneurship is not finance, but the belief to win. Often our minds are shackled by material constraints (Capital, Place, Product) to start a business. Sometimes we get stuck and we focus too much on those boundaries that we can't move forward.

2. Be friendly with an uncertainty. Being an entrepreneur means that we are ready to make friends with uncertainty. Attitudes to things that are uncertain are not planned and may not be measured. Uncertainty is not to be avoided, deal with uncertainty with research, data and entrepreneurial institutions. Approach and adapt to uncertainty.

3. Open mind learn new things. Being an entrepreneur will put you in a new environment that is completely foreign. An environment can not only shape us into successful entrepreneurs, but also be able to thwart our steps forward. Learn, observe and innovate the behavior of our new environment, have fast leaner ability to stay afloat.

4. Be ready prepare yourself well. Prepare is an important factor in success. Prepare and improve our skills before jumping into the line of business that will be occupied. Enrich with small research on the market that we will be working on.

5. Show a face that is interesting to see in the form of a network. Entrepreneurs are not people who are successful on their own, meaning they always need help from other people, friends, parents, suppliers, or other business relationships. Improve our appearance with a smile, friendly, pleasing to the eye and enthusiastic, use these strengths to expand our network.

6. Reduce risk by supporting data, information, as well as technical capabilities. Do not forget that accurate data will be our best friend in dealing with the risks that arise. Dig and examine the data and information related to the field.

\section{References}

Dareck, Carol.2006. Change Your Mindset Your Life. Jakarta : Serambi

Gladwell, M. 2008. Outliers: Story of Success. New York : Litle Brown and Companny

Hassobah, Z.I. 2004. Developing Creative and Cretical Thingking Skill. Bandung : Nuansa

Harrington, Scott E., dan Gregor R. Niehaus. 2004. Risk Management and Isurance. $2^{\text {nd }}$ Ed.NY : McGraw

Koestenbaum, P. 2002. Leadership : The Inner Side of Greatness : A Philosophy For Leader : San Francisco : Josssey-Bass

Kyosaki, R.T. 2002. Guide to Investing. Jakarta : Gramedia

Lum.Michael.2008.NLP Scret. Jakarta: Mitra Media

Maxwll, J.C. 2007. Tallen is Never Enough: Discover The Choices That Will Take You Beyond Your Tallen. California : Thomas Nelson, Inc

Maxwell, J.C. 2002. Leadership 101 : What every Leader Need ti Know. Tennessee: Thomas Nelson, Inc. Naryono, E. 2020. Pedoman Penulisan Skripsi Program Sarjana. Sukabumi : P3M STIE PASIM

Naryono, E. 2020. Strategi Pemasaran. Sukabumi : P3M STIE PASIM

Overton, R.2002. Improve Your Management Skill. Warton Book

Sherwood. 2006. Innovation and Creativity. Jakarta : Elex Media

Word book, 2008. The Word book Encyclopedia. Chicago : World Book, Inc 